\title{
Azithromycin - more than an antibiotic
}

Azytromycyna - antybiotyk i nie tylko

\author{
$12^{\text {nd }}$ Department of Paediatrics, Centre of Postgraduate Medical Education, Warsaw, Poland \\ ${ }^{2}$ Department of Paediatrics and Neonatology, Central Clinical Hospital of the Ministry of the Interior, Warsaw, Poland \\ Correspondence: Associate Professor Adam J. Sybilski, MD, PhD, Department of Paediatrics and Neonatology, Central Clinical Hospital of the Ministry of the Interior, Wołoska 137, 02-507 Warsaw, Poland, \\ e-mail: adam.sybilski@cskmswia.pl
}

\begin{abstract}
Azithromycin, which belongs to the azalide subclass, is a derivative of erythromycin, obtained by inserting a methyl substituted nitrogen atom into the lactone ring. In this way, better stability at the low $\mathrm{pH}$ of the gastric juice, improved bioavailability, and an extended half-life relative to erythromycin were achieved. The mechanism of azithromycin antibacterial activity is to inhibit bacterial cell protein synthesis by binding to the $50 \mathrm{~S}$ ribosomal subunit and preventing bacterial mRNA translation and protein biosynthesis. In addition to bactericidal activity, azithromycin also has immunomodulatory, anti-inflammatory, and antiviral properties. For this reason, it is used in exacerbations of asthma and chronic obstructive pulmonary disease. However, its antibacterial efficacy and high safety are most important. In clinical practice, several model clinical profiles of patients can be presented: children with community-acquired Mycoplasma pneumoniae pneumonia, recurrent respiratory tract infections and exacerbations of chronic inflammations, acute bronchitis of likely bacterial aetiology, tonsillitis and allergy to $\beta$-lactam antibiotics, and pertussis. Efficacy has also been proven in primary skin and soft tissue infections as well as erysipelas. However, azithromycin may also have an unusual use, as confirmed by recent reports. These include travellers' diarrhoea, cat scratch disease (bartonellosis - rickettsiosis), and mycobacteriosis (nontuberculous mycobacteria). Appropriate spectrum of action, efficacy and safety, as well as a low percentage of resistant bacteria, good bioavailability, easy to remember, practical and simple dosage regimen and optimal cost are features of a good antibiotic. Azithromycin is close to meeting all these criteria.
\end{abstract}

Keywords: azithromycin, antibiotic, immunomodulatory, anti-inflammatory effect

Streszczenie Azytromycyna, należąca do podklasy azalidów, jest pochodną erytromycyny, uzyskaną przez wstawienie do pierścienia laktonowego atomu azotu podstawionego grupą metylową. W ten sposób osiągnięto lepszą stabilność w niskim pH soku żołądkowego, lepszą biodostępność i wydłużony okres półtrwania w stosunku do erytromycyny. Mechanizm przeciwbakteryjnego działania azytromycyny polega na hamowaniu syntezy białek komórki bakteryjnej poprzez wiązanie się z podjednostką 50 S rybosomu i uniemożliwieniu translacji bakteryjnego mRNA oraz biosyntezy białek. Oprócz działania bakteriobójczego azytromycyna wykazuje również właściwości immunomodulujące, przeciwzapalne i przeciwwirusowe. Z tego względu jest stosowana w zaostrzeniach astmy i przewlekłej obturacyjnej choroby płuc. Jednak najważniejsze są jej skuteczność przeciwbakteryjna oraz wysokie bezpieczeństwo. W praktyce klinicznej można przedstawić kilka modelowych profili klinicznych pacjentów: dzieci z pozaszpitalnym zapaleniem płuc o etiologii Mycoplasma pneumoniae, z nawracającymi infekcjami dróg oddechowych i zaostrzeniami przewlekłych zapaleń, z ostrym zapaleniem oskrzeli o prawdopodobnej etiologii bakteryjnej, z anginą i uczuleniem na antybiotyki $\beta$-laktamowe, z krztuścem. Skuteczność azytromycyny udowodniono też w pierwotnych zakażeniach skóry i tkanek miękkich oraz róży. Jednak, co uzasadniają ostatnie doniesienia, azytromycyna może mieć również nietypowe zastosowania, np. w biegunce podróżnych, chorobie kociego pazura (bartoneloza - riketsjoza) czy mykobakteriozie (prątki niegruźlicze). Cechy dobrego antybiotyku to: odpowiednie spektrum działania, skuteczność, bezpieczeństwo, niski odsetek opornych bakterii, dobra biodostępność, łatwy do zapamiętania i zastosowania, praktyczny oraz prosty schemat dawkowania, a także optymalny koszt. Azytromycyna jest bliska spełnienia tych warunków.

Słowa kluczowe: azytromycyna, antybiotyk, działanie immunomodulacyjne, przeciwzapalne 


\section{INTRODUCTION}

A ntibiotics are a group of agents that are commonly used in daily practice. Since the discovery of penicillin by Alexander Fleming, it is impossible to imagine medicine (proper and effective treatment) without antimicrobials. The choice (usually empirical) of an appropriate antibiotic is the key element in the treatment of infections. This choice should be based on the knowledge of the most common aetiological factors and current epidemiological research on bacterial susceptibility to antibiotics in a given region. Undoubtedly, the natural course of infection, the type of symptoms and the affected organ(s), as well as the patient's age and comorbidities also need to be considered.

Macrolides, including azithromycin (AZT) belonging to the subclass of azalides, have an established role in the treatment of infections. Azithromycin is a derivative of erythromycin, obtained by inserting a methyl substituted nitrogen atom into the lactone ring. In this way, better stability at the low $\mathrm{pH}$ of the gastric juice, improved bioavailability, and an extended half-life relative to erythromycin were achieved.

\section{MECHANISMS OF ACTION}

\section{Bacteriostatic effects}

The mechanism underlying azithromycin antibacterial activity involves inhibition of bacterial cell protein synthesis by binding to the $50 \mathrm{~S}$ ribosomal subunit and preventing bacterial mRNA translation and protein biosynthesis.

The antimicrobial spectrum of azithromycin includes gram-positive cocci: staphylococci (Staphylococcus aureus) and streptococci (Streptococcus pyogenes, Streptococcus pneumoniae, Streptococcus agalactiae), selected gram-negative bacteria (Haemophilus influenzae, Haemophilus parainfluenzae, Moraxella catarrhalis, Legionella pneumophila, Neisseria gonorrhoeae) and the so-called atypical bacteria (Chlamydophila pneumoniae, Chlamydia trachomatis, Mycoplasma pneumoniae $)^{(1)}$. In the case of staphylococci and streptococci, there is complete cross-resistance with other macrolides. Detection of resistance to erythromycin in these microbes in vitro indicates clinical resistance to all macrolides. It should be remembered, however, that there are studies showing clinical benefits of azithromycin in resistant strains due to immunomodulation ${ }^{(2)}$.

\section{Immunomodulatory effect}

Depending on the levels and therapy duration, the
Its immunomodulatory effects become apparent with a long-term use. This occurs through several pathways: effectively reduced phagocytic respiratory bursts, and reduced production and release of pro-inflammatory and inflammatory factors [tumour necrosis factor $\alpha$ (TNF- $\alpha)$, interferon $\gamma($ IFN- $\gamma)$, interleukins IL-1, IL-6, IL-8, IL-10] from leukocytes and respiratory epithelial cells. Additionally, stimulation of the secretory activity of human neutrophils, which contributes to the regulation of the expression of genes involved in cytokine synthesis in eukaryotic cells, occurs. Azithromycin inhibits the activity of the nuclear factor kappa-light-chain-enhancer of activated B cells (NF- $\mathrm{KB}$ ) in TNF-stimulated $\mathrm{T}$ cells, increases cyclic adenosine monophosphate (cAMP) levels in respiratory epithelial cells (which would partially explain the ability of macrolides to inhibit production of inflammatory mediators), increases apoptosis, which prevents the release of pro-inflammatory factors from dead neutrophils, as well as stimulates degranulation of unstimulated neutrophils. At the same time, it reduces the influx of neutrophils into the bronchial secretion stimulated by bacterial lipopolysaccharide (LPS), which reduces the production of mucus.

\section{Anti-inflammatory effect}

The anti-inflammatory effects of azithromycin are due to its immunomodulatory action. Activation of inhibition of the transcription factor NF- $\mathrm{KB}$ is the main pathway used. There are many clinical reports confirming that azithromycin reduces inflammation and accelerates healing, regardless of the aetiology of inflammation ${ }^{(4-6)}$. This effect is used, among other things, in the case of topical application of the antibiotic $^{(7)}$.

\section{Antiviral effect}

It has been known for several years that azithromycin shows antiviral activity, as shown in clinical trials, both in vitro and in vivo. This effect is best documented for rhinoviruses and influenza viruses ${ }^{(8)}$. However, its mechanism of action has not been fully understood. Reduction of the intercellular adhesion molecule 1 (ICAM-1), the main receptor for rhinoviruses, may be a possible explanation for the antiviral effects of azithromycin. At the same time, azithromycin was shown to increase the expression of type I and III interferons in bronchial epithelial cells in response to RV-16 infection and to increase the production of RIG-I-like helicase (an enzyme that catalyses viral DNA strand separation). This is important as interferons are a group of cytokines produced and released by cells in response to viral infection and they play a key role in antiviral response. Many studies suggest that macrolides inhibit rhinoviral replication ${ }^{(9,10)}$. 


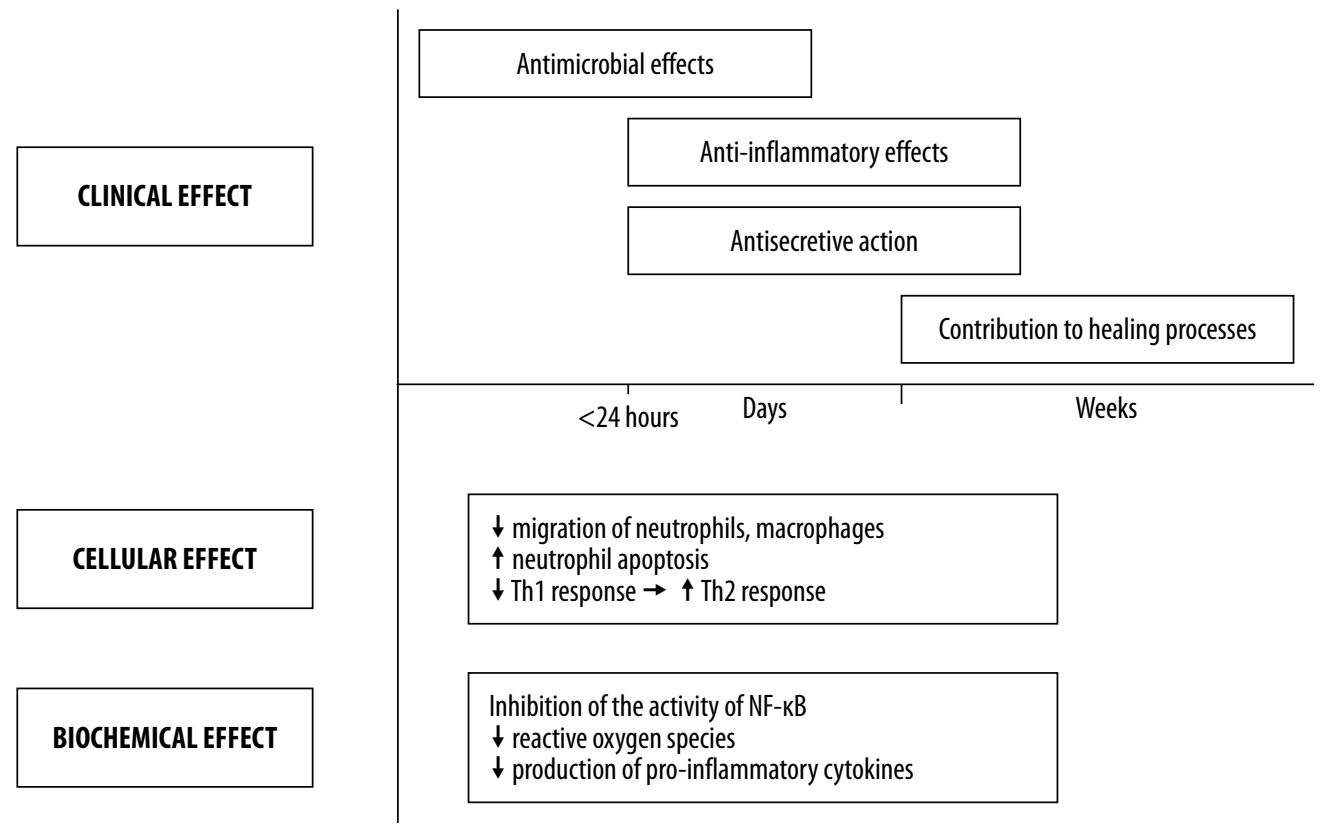

Fig. 1. Bacteriostatic and immunomodulatory effects of azithromycin depending on the time of administration ${ }^{(3)}$

\section{TYPICAL CLINICAL PROFILES OF PATIENTS WHO MAY BE TREATED WITH AZITHROMYCIN}

\section{Patients with Mycoplasma pneumoniae community-acquired pneumonia}

Macrolides are treatment of choice in respiratory infections caused by atypical bacteria (Mycoplasma pneumoniae, Chlamydophila pneumoniae, Legionella pneumophila). This is supported by both the Recommendations for the Management of Community-Acquired Respiratory Infections (Rekomendacje postępowania $w$ pozaszpitalnych zakażeniach układu oddechowego) and The Sanford Guide to Antimicrobial Therapy 2020 (Przewodnik antybiotykoterapii 2020)(11,12). A macrolide should be used in a patient suspected of or already diagnosed with mycoplasmal pneumonia. Azithromycin shows high efficacy against atypical bacteria. This is because it perfectly penetrates tissues and body fluids (better than other macrolides). This contributes to a much greater antimicrobial efficacy, especially against intra-tissue bacteria (e.g. Mycoplasma pneumoniae). Many studies in large, diverse groups of patients clearly indicate efficacy and safety of such treatment ${ }^{(13,14)}$. Macrolides are first choice in this type of cases in all age groups, although a Cochrane meta-analysis published in recent years indicates the need for further research ${ }^{(15)}$.

\section{A patient with infectious asthma exacerbation}

Infections (mainly viral) are the most common cause of asthma exacerbations. Recently, there has been an increase in asthma exacerbations caused by infections with atypical bacteria. These observations encourage the choice of azithromycin. Furthermore, its broad spectrum of action allows for the effective treatment of infective exacerbations of asthma of other aetiology. Yet its another beneficial property, i.e. immunomodulatory and anti-inflammatory effects, also reduces the severity of asthma symptoms and the duration of asthma episodes in young children, suggesting that this drug may play an important role in the acute management of exacerbations. Research also shows that azithromycin has beneficial effects on the long-term course of the disease ${ }^{(16)}$.

\section{A patient with acute bronchitis of likely bacterial aetiology}

In her 2015 meta-analysis, Cochrane showed statistically significantly less common therapeutic failures after azithromycin vs. amoxicillin alone or in combination with clavulanic acid. Also, adverse effects were less common in patients on azithromycin ${ }^{(17)}$.

Azithromycin clearly shows higher in vitro efficacy than clarithromycin (up to $20 \%$ of resistant strains) or erythromycin (full resistance in clinical practice) against some gram-negative bacteria, such as Haemophilus influenzae.

\section{A patient with tonsillitis and allergy to $\beta$-lactams}

Penicillins and $\beta$-lactam antibiotics are the treatment of choice for streptococcal tonsillitis. At the same time, this class of antibiotics in the most common cause of drug allergies (up to $30 \%$ ). Macrolides are first line treatment in streptococcal tonsillitis in patients with allergy to $\beta$-lactams. 
Short-course antibiotic treatment is currently recommended (3-5 days) ${ }^{(11,12)}$.

\section{A patient with pertussis}

Early decision to initiate pharmacotherapy increases the chance for full recovery and prevents complications. Macrolides are treatment of choice. Azithromycin is particularly recommended for children due to a more convenient dosage (once daily) and a reduced number of adverse effects (gastrointestinal in particular). It is especially recommended for children under 1 year of age ${ }^{(11,12)}$.

\section{UNUSUAL USES OF AZITHROMYCIN}

\section{Skin and soft tissue infections}

Cellulitis is an inflammation of the skin and the subcutaneous tissue. Primary skin and soft tissue infections affect an otherwise healthy skin and are most often caused by group A streptococci or Staphylococcus aureus. In the case of allergy to $\beta$-lactams, azithromycin is indicated. Erysipelas, i.e. acute inflammation of the skin and the subcutaneous tissue caused by group A streptococci (Streptococcus pyogenes), is another disease for which macrolide may be considered. A 2016 meta-analysis showed that treatment with macrolide (including azithromycin) in patients with cellulitis or erysipelas shows a similar efficacy and rates of adverse effects as treatment with beta-lactams ${ }^{(18)}$.

\section{Chlamydia trachomatis infections}

Chlamydia trachomatis is a gram-negative bacterium, which infects the cylindrical epithelium of the cervix, urethra and the rectum, as well as non-genital sites. This bacterium is the cause of chlamydiosis the most commonly reported sexually transmitted disease. Genitourinary infections primarily occur in young adults and individuals with multiple sexual partners. The majority of patients infected with Ch. trachomatis are asymptomatic. If present, the most common symptoms in women include abnormal vaginal discharge, vaginal bleeding and dysuria. However, the infection can cause serious complications, such as scarring of the fallopian tubes, infertility, and ectopic pregnancy. In men, the symptoms may include discharge from the penis, itchiness, and dysuria. Doxycycline is the treatment of choice; however, uncomplicated genitourinary chlamydial infection can be treated with azithromycin ( $1 \mathrm{~g}$, single dose). The efficacy of azithromycin (97\%) is similar to that of doxycycline $(100 \%)^{(19)}$.

\section{Traveller's diarrhoea}

Traveller's diarrhoea is a set of symptoms caused travellers taking trips outside their countries (mainly Asia, Africa, Mexico, Central and South America). Bacteria ( $80 \%$ of cases) responsible for traveller's diarrhoea include enterotoxic and enteropathogenic strains of Escherichia coli, Salmonella spp., Shigella spp., Campylobacter jejuni, Yersinia enterocolitica and Vibrio cholerae. Azithromycin is a well-established drug in the prevention and treatment of traveller's diarrhoea. For those travelling to Southeast Asia, where there is high resistance to fluoroquinolones, azithromycin is the prophylaxis of choice (500 mg daily for 3 days or 1,000 mg as a single dose). Due to its high safety and efficacy, azithromycin is the treatment of choice (self-administered by the patient) for traveller's diarrhoea in children and pregnant women. It shows efficacy in infections caused by both invasive and non-invasive pathogens. Medical consultation and faecal culture are usually not needed in travellers who return from their trips with uncomplicated diarrhoea. In such cases, many authors advise patients to decide on their own whether to use azithromycin at standard doses ${ }^{(20-22)}$.

\section{Cat scratch disease - bartonellosis (rickettsiosis)}

Cat scratch disease (CSD) is a bacterial zoonotic disease caused by intracellular rods of the genus Bartonella, belonging to the order Rickettsiales (mainly Bartonella henselae). The main symptoms of this infection are fever or lymphadenopathy near the scratch, and a bump, pustule, or blister. Since CSD is not a common disease, therapeutic management is based on case reports. Latest reports indicate that azithromycin is the most appropriate management. Doxycycline can be optionally used; however, the drug is contraindicated in children (under the age of 8 years in Poland) and pregnant women. In typical uncomplicated cases, azithromycin is administered for 5 days (therapy continuation for several weeks is needed in some cases) ${ }^{(23-25)}$.

\section{Mycobacterioses - nontuberculous bacilli}

Mycobacterioses are infections caused by acid-fast mycobacteria other than tuberculosis and leprosy mycobacteria. The global prevalence of mycobacterioses is on the rise. They can cause diseases of the skin, soft tissues, lymph nodes, and the osteoarticular system; however, pneumonia of varying location and severity is the most common manifestation. Azithromycin (usually at $250 \mathrm{mg} /$ day, $500 \mathrm{mg} /$ day for 5 days if needed) in combination with rifampicin or ethambutol is used in all treatment regimens ${ }^{(26,27)}$. Cumulative data from the assessment of the efficacy of macrolide therapy (including azithromycin) for lung diseases caused by Mycobacterium avium have shown that azithromycin is effective, safe and well tolerated in the treatment of mycobacterioses ${ }^{(28)}$. 


\section{Erythema migrans - Lyme disease}

Lyme disease is a multiorgan disease caused by the spirochetes caused by Borrelia burgdorferi sensu lato (in Poland these are: B. burgdorferi, B. garinii, B. afzelii), transmitted by ticks (Ixodes), the clinical picture of which is characterised by the involvement of the skin, joints, nervous system and heart. Erythema migrans, which appears at the site of the tick bite, is the initial symptom of the disease. A typical lesion initially appears in the form of a spot, which rapidly expands, showing a central clearing. Doxycycline, amoxicillin and cephalosporin administered for 21 days is a standard treatment for this form of Lyme disease. In case of hypersensitivity to $\beta$-lactam antibiotics, azithromycin $(1 \times 500 \mathrm{mg}$; children: $10 \mathrm{mg} / \mathrm{kg} /$ day for $7-10$ days $)$ is recommended ${ }^{(29)}$.

\section{EXAMPLES OF NON-STANDARD USE OF AZITHROMYCIN}

\section{Prevention of exacerbations of pulmonary symptoms in patients with primary immune deficiencies}

Patients with primary immune deficiencies and impaired production of antibodies often develop airway infections. This leads to chronic pulmonary damage. Researchers from Italy conducted a 3 -year, randomised double-blind, placebo-controlled clinical trial to verify whether oral azithromycin ( $250 \mathrm{mg}$ once daily 3 times a week for 2 years) would reduce the number of respiratory exacerbations in these patients. The number of exacerbations was 3.6 [95\% confidence interval (CI) 2.5-4.7] per patient per year in the azithromycin group and 5.2 (95\% CI 4.1-6.4) per patient per year in the placebo group $(p=0.02)$. Also, the rates of repeated antibiotic treatment were significantly lower in patients receiving azithromycin ( 2.3 vs. $3.6 ; p=0.004)$. Thus, long-term administration of azithromycin can be an effective prophylaxis in immunocompromised patients ${ }^{(30)}$.

\section{Treatment of non-infective exacerbations of asthma in children}

Danish researchers found that azithromycin reduces the duration of asthma episodes in young children, suggesting that the drug may play an important role in the acute management of asthma exacerbations. They documented their conclusions in a study in a group of 72 children aged 1-3 years (mean age 2 years), which showed a reduced duration of episodes of cough, dyspnoea and wheezing unrelated to infection. Asthma exacerbations were $63.3 \%$ shorter in children treated with azithromycin (3.4 vs. 7.7 days; $95 \%$ CI $56.0-69.3 ; p<0.0001$ ). Additionally, better outcomes were obtained if the drug was administered earlier, within 6 days of symptom onset $^{(31)}$.

\section{Treatment of COPD and asthma caused by viral infections}

Rotavirus infections are one of the most common (20-55\%) causes of exacerbation of chronic obstructive pulmonary disease (COPD) and asthma, and contribute to their severity. Scientific reports indicate that the antiviral and immunomodulatory effects of azithromycin may reduce the frequency of COPD exacerbations. Menzel et al. suggested that azithromycin may reduce the incidence of COPD and asthma exacerbations, especially those caused by viral infections. Importantly, this effect was observed at azithromycin levels achieved during treatment with standard therapeutic doses ${ }^{(9,32)}$.

\section{Treatment of asthma}

Recently, a meta-analysis of 8 clinical trials, assessing the effects of azithromycin (doses of 250-600 mg for several weeks in various regimens) on the course of asthma. The analysis showed that adjuvant treatment with azithromycin in patients with asthma can improve forced expiratory volume in 1 second $\left(\mathrm{FEV}_{1}\right)$. However, no statistically significantly reduced asthma exacerbations, increased peak expiratory flow (PEF), improved quality of life or reduced levels of nitric oxide in the exhaled air (fractional exhaled nitric oxide, FeNO) were observed. The authors suggested that further research is needed to define the role of azithromycin in the treatment of asthma more precisely ${ }^{(33)}$.

\section{Treatment of influenza with oseltamivir/ azithromycin combination}

In cases of severe infection with influenza virus, antibiotic therapy along with standard antiviral therapy may be an effective treatment option, especially since in most cases severe influenza infection is associated with secondary bacterial superinfection, pneumonia in particular. Combination therapy with oseltamivir and azithromycin $(\mathrm{AV}+\mathrm{AZT})$ was found to be more effective in preventing complications associated with influenza A (H1N1) infection compared to oseltamivir alone. Influenza complications, such as secondary bacterial infection, were statistically significantly reduced, and the hospitalisation time of patients in the AV + AZT group was also shorter. The mean symptom severity score (on days 3 and 5) was also lower in these patients, showing faster recovery from this severe disease in patients on combination therapy. Inclusion of azithromycin in standard antiviral treatment as an adjunct therapy can be an effective treatment protocol, especially in high-risk patients, such as elderly and unvaccinated patients ${ }^{(8)}$. 


\section{CHARACTERISTICS OF AN IDEAL ANTIBIOTIC VS. AZITHROMYCIN}

There is no such thing as an ideal antibiotic. However, there are certain characteristics that a well-chosen drug should have. Does azithromycin meet the criteria of a good antibiotic?

- The spectrum of antimicrobial action - antibiotics with therapeutic spectrum covering potential aetiological factors are recommended. Azithromycin is primarily used as a first-choice antibiotic in the treatment of atypical infections, but its broad spectrum action (bacteriostatic action against the most common aetiological factors of respiratory tract infections) can be effectively used in other bacterial infections.

- An antibiotic should be effective, which is measured primarily by the improvement of the patient's health (clinical effect), normalisation of biochemical inflammatory markers (leukocytosis, C-reactive protein and procalcitonin levels) and elimination of the pathogen from the focus of infection, which can be confirmed by microbiological examination. Many reports indicate the efficacy of azithromycin in respiratory tract infections ${ }^{(34,35)}$ and other indications ${ }^{(18-20)}$.

- Additionally, the efficacy depends on the low percentage of bacteria resistant to a given antibiotic. A recently published meta-analysis from the Cochrane database presents 5 reports showing that the percentage of azithromycin-resistant bacteria after many weeks (4-52 weeks) of therapy with antibiotic vs. placebo is identical ${ }^{(36)}$. Data presented by the Centers for Disease Control and Prevention (CDC) indicate that the resistance of Streptococcus pneumoniae to macrolides (including azithromycin) is comparable to resistance to penicillins in Poland ${ }^{(37)}$.

- Great importance is attached to the safety of an antibiotic, the frequency and severity of adverse effects, contraindications to its use and interactions with other drugs. A safe antibiotic should pose no serious risks to the patient, and if any, the risks should not outweigh those associated with the infection itself. The safety of azithromycin is very well documented. Additionally, unlike clarithromycin, it does not affect cytochrome P450, which increases its safety. It is also less likely to interact with other drugs (e.g. theophylline, cimetidine and fentanyl). The safety was also confirmed by Food and Drug Administration qualification of azithromycin as category B of drugs used in pregnancy (no studies conducted in humans, no adverse effects in animals - drugs can be used $)^{(1)}$.

- Bioavailability of the drug (which determines the possibility of mixing the drug with a meal in young children) and good taste are also important in children. Inserting a methyl substituted nitrogen atom into the lactone ring improved stability of azithromycin at the low $\mathrm{pH}$ of the gastric juice and its bioavailability compared to erythro-
- Easy to remember and apply, practical and simple dosing regimen determines good compliance. Due to the pharmacokinetic and pharmacodynamic properties of azithromycin, it can be taken once daily, with standard treatment lasting 3-5 days ${ }^{(38)}$.

- Both patients and doctors should also consider the costs of treatment (optimal cost is defined as eliminating the infection by bearing the lowest direct and indirect costs possible). It may be argued that azithromycin preparations meet the optimal cost criterion.

The presented review of the mechanisms of action, profiles of typical patients and non-standard applications of azithromycin shows that this antibiotic is an effective and safe form of treatment of infections (respiratory tract infections in particular) and may find a place in the treatment of some chronic diseases.

\section{Conflict of interest}

Author does not report any financial or personal connections with other persons or organizations, which might negatively affect the contents of this publication and/or claim authorship rights to this publication.

\section{References}

1. Parnham MJ, Erakovic Haber V, Giamarellos-Bourboulis EJ et al.: Azithromycin: mechanisms of action and their relevance for clinical applications. Pharmacol Ther 2014; 143: 225-245.

2. Yamada K, Yanagihara K, Kaku N et al.: Azithromycin attenuates lung inflammation in a mouse model of ventilator-associated pneumonia by multidrug-resistant Acinetobacter baumannii. Antimicrob Agents Chemother 2013; 57: 3883-3888.

3. Cramer CL, Patterson A, Alchakaki A et al.: Immunomodulatory indications of azithromycin in respiratory disease: a concise review for the clinician. Postgrad Med 2017; 129: 493-499.

4. Cheung PS, Si EC, Hosseini K: Anti-inflammatory activity of azithromycin as measured by its NF- $\mathrm{\kappa B}$ inhibitory activity. Ocul Immunol Inflamm 2010; 18: 32-37.

5. Li DQ, Zhou N, Zhang L et al.: Suppressive effects of azithromycin on zymosan-induced production of proinflammatory mediators by human corneal epithelial cells. Invest Ophthalmol Vis Sci 2010; 51: 5623-5629.

6. Steel HC, Theron AJ, Cockeran R et al.: Pathogen- and host-directed anti-inflammatory activities of macrolide antibiotics. Mediators Inflamm 2012; 2012: 584262.

7. Ikemoto K, Kobayashi S, Haranosono Y et al.: Contribution of anti-inflammatory and anti-virulence effects of azithromycin in the treatment of experimental Staphylococcus aureus keratitis. BMC Ophthalmol 2020; 20: 89.

8. Ishaqui AA, Khan AH, Sulaiman SAS et al.: Assessment of efficacy of Oseltamivir-Azithromycin combination therapy in prevention of Influenza-A (H1N1)pdm09 infection complications and rapidity of symptoms relief. Expert Rev Respir Med 2020; 14: 533-541.

9. Menzel M, Akbarshahi H, Tufvesson E et al.: Azithromycin augments rhinovirus-induced IFN $\beta$ via cytosolic MDA5 in experimental models of asthma exacerbation. Oncotarget 2017; 8: 31601-31611.

10. Gielen V, Johnston SL, Edwards MR: Azithromycin induces antiviral responses in bronchial epithelial cells. Eur Respir J 2010; 36: 646-654.

11. Dzierżanowska D, Nitsch-Osuch A: Przewodnik antybiotykoterapii 2020. $25^{\text {th }}$ ed., Alfa Medica Press, Bielsko-Biała 2020. 
12. Hryniewicz W, Albrecht P, Radzikowski A (eds.): Rekomendacje postępowania w pozaszpitalnych zakażeniach układu oddechowego. Narodowy Instytut Leków, Warszawa 2016: 25-36.

13. Biondi E, McCulloh R, Alverson B et al.: Treatment of mycoplasma pneumonia: a systematic review. Pediatrics 2014; 133 : 1081-1090.

14. Mulholland S, Gavranich JB, Gillies MB et al.: Antibiotics for community-acquired lower respiratory tract infections secondary to Mycoplasma pneumoniae in children. Cochrane Database Syst Rev 2012; (9): CD004875.

15. Gardiner SJ, Gavranich JB, Chang AB: Antibiotics for community-acquired lower respiratory tract infections secondary to $\mathrm{Myco}$ plasma pneumoniae in children. Cochrane Database Syst Rev 2015; 1: CD004875.

16. Brusselle GG, VanderStichele C, Jordens P et al.: Azithromycin for prevention of exacerbations in severe asthma (AZISAST): a multicentre randomised double-blind placebo-controlled trial. Thorax 2013; 68: 322-329.

17. Laopaiboon M, Panpanich R, Swa Mya K: Azithromycin for acute lower respiratory tract infections. Cochrane Database Syst Rev 2015; 2015 (3): CD001954.

18. Ferreira A, Bolland MJ, Thomas MG: Meta-analysis of randomised trials comparing a penicillin or cephalosporin with a macrolide or lincosamide in the treatment of cellulitis or erysipelas. Infection 2016; 44: 607-615.

19. Geisler WM, Uniyal A, Lee JY et al.: Azithromycin versus doxycycline for urogenital Chlamydia trachomatis infection. N Engl J Med 2015; 373: 2512-2521.

20. Steffen R: Epidemiology of travellers' diarrhea. J Travel Med 2017; 24 Suppl 1: S2-S5.

21. Steffen R, Hill DR, DuPont HL: Traveler's diarrhea: a clinical review. JAMA 2015; 313: 71-80.

22. Giddings SL, Stevens AM, Leung DT: Traveler's diarrhea. Med Clin North Am 2016; 100: 317-330.

23. Guiyedi V, Haddad H, Okome-Nkoumou M et al.: Cat-scratch disease in adult hospitalized for prolonged-fever associated with multiple lymphadenopathies and weight loss. Open Microbiol J 2013; 7: 152-155

24. Chang CC, Lee CJ, Ou LS et al.: Disseminated cat-scratch disease: case report and review of the literature. Paediatr Int Child Health 2016; 36: 232-234.

25. Shorbatli LA, Koranyi KI, Nahata MC: Effectiveness of antibiotic therapy in pediatric patients with cat scratch disease. Int J Clin Pharm 2018; 40: 1458-1461.
26. Daley CL: Mycobacterium avium complex disease. Microbiol Spec$\operatorname{tr} 2017 ; 5$.

27. Kwon YS, Koh WJ, Daley CL: Treatment of Mycobacterium avium complex pulmonary disease. Tuberc Respir Dis (Seoul) 2019; 82: 15-26.

28. Wallace RJ Jr, Brown-Elliott BA, McNulty S et al.: Macrolide/ azalide therapy for nodular/bronchiectatic Mycobacterium avium complex lung disease. Chest 2014; 146: 276-282.

29. Pancewicz S, Moniuszko-Malinowska A, Garlicki A et al.: Diagnostyka i leczenie boreliozy z Lyme. Standardy Polskiego Towarzystwa Epidemiologów i Lekarzy Chorób Zakaźnych. Białystok, Kraków 2018. Available from: http://www.pteilchz.org.pl/wp-content/ uploads/2018/11/borelioza_z_lyme_2018.pdf.

30. Milito C, Pulvirenti F, Cinetto F et al.: Double-blind, placebo-controlled, randomized trial on low-dose azithromycin prophylaxis in patients with primary antibody deficiencies. J Allergy Clin Immunol 2019; 144: 584-593.

31. Stokholm J, Chawes BL, Vissing NH et al.: Azithromycin for episodes with asthma-like symptoms in young children aged 1-3 years: a randomised, double-blind, placebo-controlled trial. Lancet Respir Med 2016; 4: 19-26.

32. Menzel M, Akbarshahi H, Bjermer L et al.: Azithromycin induces anti-viral effects in cultured bronchial epithelial cells from COPD patients. Sci Rep 2016; 6: 28698.

33. Wang $X$, Luo J, Wang $D$ et al.: The efficacy and safety of long-term add-on treatment of azithromycin in asthma: a systematic review and meta-analysis. Medicine (Baltimore) 2019; 98: 38: e17190.

34. Ren H, Liu Y, Zhou J et al.: Combination of azithromycin and gentamicin for efficient treatment of Pseudomonas aeruginosa infections. J Infect Dis 2019; 220: 1667-1678.

35. Luo YJ, Wen XY, Ni XL et al.: Efficacy and safety of Xiyanping injection combined with azithromycin in treating Mycoplasma pneumonia of children: meta-analysis. Zhongguo Zhong Yao Za Zhi 2018; 43: 2153-2161.

36. Hansen MP, Scott AM, McCullough A et al.: Adverse events in people taking macrolide antibiotics versus placebo for any indication. Cochrane Database Syst Rev 2019; 1 (1): CD011825.

37. The Center for Disease Dynamics, Economics \& Policy: Antibiotic Resistance. Available from: https://resistancemap.cddep.org/ AntibioticResistance.php.

38. Charakterystyka Produktu Leczniczego Azycyna. Available from: http://leki.urpl.gov.pl/files/25_Azycyna_tab_pow_500.pdf. 